\title{
ORGANIZATIONAL DEMOCRACY, ETHICS AND LEADERSHIP: THE MEDIATING ROLE OF ORGANIZATIONAL POLITICS
}

\author{
Dr Martin Clarke \\ Cranfield School of Management \\ Cranfield \\ Bedford \\ England \\ MK43 OAL \\ Tel: $44+(0) 1234751122$ \\ Fax: $44+(0) 1234751908$ \\ martin.clarke@cranfield.ac.uk
}

\section{Martin Clarke BSc PhD}

Martin has worked in the manufacturing and distribution sectors and, prior to joining Cranfield, was a director with a subsidiary of a European business information company. He is a senior lecturer in management development and works with a range of international companies, advising on strategy, management development and organization change. He has published widely in both academic and practitioner journals on the subjects of organization politics, organization democracy, creating change through individual action and the role of management development in stimulating this change. He is Director of the Cranfield General Management Programmes. 


\section{ABSTRACT}

There has been a growing concern amongst commentators about the disconnection between the apparent pluralisation of society and the relatively limited adoption of democratic practices in the corporate work place. This paper examines the experience of employees in an international broking company to explore the extent to which a political leadership perspective can provide insight into furthering organizational democratisation. Attention is given to the integral relationship between democracy, ethics and a political mindset, and the influence this has upon others. In the account reported here, the ethical and developmental agenda of one influential senior manager is central to both the enactment of politics and the form of democratisation which it enables.

\section{KEY WORDS}

Ethics, Organizational Democracy, Organizational Politics, Power 
Ongoing debate about the dissonance between state and workplace democracy highlights enduring concerns about effective approaches to organizational governance (Etzioni, 1998; Harrison and Freeman, 2004; Johnson, 2006). Despite significant developments capable of promoting organizational democracy such as decentralised structures and processes, the increase and interdependence of organizational stakeholders, and the need to secure employee commitment through more distributed models of leadership, command and control still dominates the enactment of organizational hierarchy (Collins, 2001).

Yet effective governance is as much to do with how organizational leaders engage their employees as it is to do with the relationship between the owners and agents of capital. As the need to respond to an ever widening number of internal and external stakeholders increases (Caldart \& Ricart 2004; Denis, Lamothe \& Langley, 2001), the assumption that board directors, through traditional hierarchy, can ensure appropriate degrees of control over the managers of capital seems increasingly problematic. An imposition of control that fails to take account of diverse employee interests is of questionable effectiveness and ethical validity.

This dilemma has promoted renewed interest in the parallel between the leadership of political institutions and the leadership of organizations as a basis for working through the contradictions of juxtaposed hierarchy and democracy. For example, Hendry (2006), in an examination of the moral vacuum created by the tension between market liberalisation and bureaucratic controls, asks what suitable role models exist for managers struggling with the entrepreneurial demands of contemporary organizational forms. He concludes that the role of management has ample precedents in the traditions of responsible political leadership, arguing that these can enable managers to build and lead communities of trust (Hendry, 2006). How the traditions of political leadership might address this issue in practice is the focus for this study.

Specifically, this paper examines the experience of employees in an international broking company to explore the extent to which a political leadership perspective might provide insight into furthering processes of organizational democratisation. Attention is given to the integral relationship between democracy, ethics and a political mindset. In the accounts presented here, the ethical agenda and developmental orientation of one influential senior manager is central to both the enactment of politics and the form of democratisation which it enables. 


\section{IN SEARCH OF DEMOCRACY}

Given the breadth of the topics reflected in this investigation, to ensure an appropriate degree of focus, the literature from which this analysis has been drawn has necessarily been carefully circumscribed. The resulting debate is intended to focus down on what really matters for this study; the actors perspective of autonomy, control and ethical motive. To this end, I acknowledge the broad theoretical difficulties that are widely recognised to remain regarding the nature of leadership as a generic concept (Grint, 2002), despite decades of research. Likewise, it is noted that the nature of democracy has been the source of fundamental debate (see for example, Lijphart, 1999) for sometime longer.

Indeed, many of the comparisons drawn between institutional and organizational democracy (Armbruster \& Gebert, 2002; Peters \& Williams, 2002; Kerr, 2004) have struggled with its multidimensional and enigmatic nature. Rousseau and Rivero (2003) note the paucity of empirical research in the area and helpfully summarise four particular dimensions that demarcate this debate: a concern for political democracy based on electoral competition (for example between shareholders, unions and employees); a concern for economic democracy, both in terms of stock ownership and pressures for more egalitarian distribution of economic power (for example, in closing the gap between executive and employee pay); a concern for electronic democracy in terms of access to, and interactivity between knowledge holders; and lastly, a concern for democratic civic virtue, referring to the beliefs, values and behaviours that support participation, trust and accountability.

Luhman's research in the area of employee owned cooperatives (2006) parallels this multidimensional approach. He views organizational democracy as a naturally eclectic mix of philosophies, a 'rational-collective' where legitimate authority is derived from the consensus of the governed (Luhman, 2006). However, like many researchers in this arena, the focus on labour owned organizations has tended to concentrate debate over the locus of economic ownership in the labour-capital relationship (see for example Cloke \& Goldsmith, 2002; de Jong \& van Witteloostuijn, 2004). Similar polarization occurs concerning the relative value of representative versus participative democracy models. For example, Kerr (2004) and Harrison and Freeman (2004) are particularly doubtful of the broad practical application of representative democracy. Johnson (2006) goes further in suggesting that the business case for varying forms of representative democracy, argued on the grounds of economic efficiency, may only serve to exacerbate asymmetric 
power relations by excluding many members from direct influence over significant areas of decision making.

Other authors contend that the business case for democratisation cannot succeed because it is at fundamentally at odds with the dominant bureaucratic and unitary model of organising (Child \& McGrath, 2001; Thompson \& Davidson, 1995). The argument that organizations are experiencing a post bureaucratic 'revolution', freeing individuals from disabling bureaucratic rules to be more responsive to free market demands, and providing fertile ground for more democratic working, is seen as simply unfounded. For example, Hales' (2002) study of four different, but ostensibly decentralised organizations showed that they retained the defining features of bureaucracy - obedience through hierarchical forms of control, centrally-imposed rules, and individual managerial responsibility and accountability. Thus, the argument goes, rather than witnessing the emergence of the democratic organizational form, we are merely observing a periodic re-structuring of bureaucracy as it realigns itself to pressures of international capitalism. Managerial behaviour is still guided and circumscribed by a hierarchy of positions such that both authorship and guardianship of rules rests with senior management. In consequence, bureaucratic rule enforcement is far from reformed, merely cleaned up as a form of 'bureaucracy lite' (Hales, 2002).

These studies suggest that trying to graft the structures of political and economic democracy onto the mainstream of organizational working may for the foreseeable future provide limited opportunity to increase employee participation. More fruitful insight might therefore be made by considering ways of building the value premises and information sharing aspects of democracy into the design of organizations what Rousseau and Rivero mean by electronic and civic culture. Indeed, following Du Gay (2000) and others, Courpasson and Dany (2003) emphasise that rules and obedience should not necessarily be viewed in contradiction to these democratic value premises. They differentiate between rules based on organizational instrumentality and those based on moral choices that seek to develop a sense of community. A tension will always exist between them, but following Selznick, they note that self-determination is the freedom to find one's place within a moral order. To make decisions using moral criteria allows individuals to acquiesce to rules that do not oppose their conception of organizational integrity. In consequence, Courpasson and Dany consider rule obedience "as an active moral conduct preserving peoples' integrity and self esteem and the cohesion of the organization" 
(2003: 1243). Obedience is thus not a reflection of blind support for managerialism, but an awareness of the absence of choice for good reason.

Negotiating the tension between instrumental and moral obedience, between unity, rules and integration on the one hand, and diversity, autonomy and individual liberty on the other, lies at the heart of organizational governance (March \& Olsen, 1995). This for Courpasson and Dany provides the potential basis for developing resilient trust and 'democratic hybrids' that implicitly encourage individuals to make private ethical choices about which processes are acceptable for organizational control, but without the power to conclude the debate themselves.

This distinction between organizationally determined moral codes (see for example Gaumnitz \& Lere, 2004) and those that emerge from everyday managerial activity now forms a significant discourse within the canon of business ethics (Brown \& Trevino, 2006; Lovell \& Fisher, 2003; Painter-Morland, 2008) that is too large to explicate here. However, critical to this perspective is the notion of ethics as a lived practice; the continual reflection upon, and debate and contestation of, individual moral choice, but not simply working to a set of organizationally determined rules (Clegg, Kornberger \& Rhodes, 2007). Watson's (2003) study is particularly useful here as it explores how ethical choices enter into the managerial activity of one unusually reflective senior manager. In his case study of Glenn Furness he notes how Glenn acknowledges the multiplicity of conflicting human values and ethical principles at play in organizations. In turn this implies the concomitant risk of an 'ethically irrational' social world in which managers are not able to access a single set of principles to solve their moral dilemmas. Nevertheless, individual managers "faced with the ethical challenges arising from having to deal with the ethical ambiguity of the social world.... will necessarily become a moral actor in their job" (Watson 2003: 173).

Like Courpasson and Dany, Watson goes on to consider the extent to which managers act 'obediently' as both ethically reactive and ethically assertive, where an ethically irrational world is treated as an opportunity to fulfil elements of a personal ethical agenda. Thus Glenn Ferness, was able to do this by framing her considerations in 'business terms': using her individual freedom to balance what she felt to be 'right', according to her personal values, with what others would consider as appropriate for the commercial performance of the organization. In this way we can consider ethical assertiveness in part as the practice of freedom and thus the social organization of this phenomenon potentially reflecting an important 
facet of workplace democracy. Working with this orientation I build upon Rousseau and Rivero's notion of 'civic culture' and define organizational democracy in terms of enhancing individual autonomy and the legitimisation of processes that enable such individuals to be critically self-reflective - to deliberate, judge, choose and act upon courses of action (Held, 1987). In this regard 'critical reflection' denotes the interrogation of ones own thinking and actions that results in the recognition of a wider range of possibilities (Dehler, citing Barnett, 2009).

\section{POLITICAL LEADERSHIP}

These kinds of deliberations as to the nature of organizational democracy and ethical leadership have inspired our own considerations as to what conditions might give rise to ethically assertive managers and how they might mediate the expression of corporate priorities. Our work (2006, 2006a, 2009) building from the traditions of political science, has explored the idea of organizational political leadership as a potential catalyst for greater workplace democracy. Whilst the analysis of political institutional leadership as a means of illuminating the practice of organizational leadership can be traced back to the seminal work of Burns (1978), we see our work as distinct from much of the current literature addressing the relationship between personality, politics and leadership (see Vigoda-Gadot \& Drory, 2006). Politics is defined here as 'those deliberate efforts made by individuals to use power in the pursuit of their own interests' (Butcher and Clarke, 2001:19). Along with several other authors (Coopey \& Burgoyne, 2000; Hendry, 2006; Morrell \& Hartley, 2006; Peele, 2005), we take the view that the traditions of institutional political activity provide a potentially valuable perspective for informing the understanding of organising in contemporary contexts, where divergent interests, contested authority and institutionalised power are embedded but contradictory features.

The nature and limitations of this parallel are explored fully in Butcher and Clarke (2006) and Clarke (2006) but in summary, in situations of contested power and diverse objectives, political behaviour in organizations, far from being dysfunctional, is central to the achievement of managerial goals. Moreover, as suggested by Grit (2004), it can constitute a vehicle to strengthen the ethical choices made by managers. As with the leadership of political institutions, responsible political behaviour can only be predicated on the assumption that business leaders possess civic virtue: the ability to balance personal and organizational interests. As Watson's study suggests, there is no evidence to 
indicate that managers are any less motivated by just causes, any less willing to forego self-serving ends, or any less prepared to distinguish between ethical and unethical means, than elected politicians.

In Clarke (2006), I attempted to identify how individual executives cope with diverse and competing political interests. Responses varied from those managers reflecting a hierarchical bureaucratic mindset to those demonstrating behaviours reflective of political leadership (figure 1 ).

Figure 1 Leadership Behaviours

\begin{tabular}{|c|c|}
\hline From Rational Leadership & To 'political' leadership \\
\hline $\begin{array}{l}\text { - Preference for formal meetings and } \\
\text { processes }\end{array}$ & $\begin{array}{l}\text { - Extensive use of informal processes, e.g. } \\
\text { covert activity, corridor meetings }\end{array}$ \\
\hline $\begin{array}{l}\text { - Focus on senior management } \\
\text { approval/buy-in }\end{array}$ & $\begin{array}{l}\text { - Focus on working with personal } \\
\text { agendas }\end{array}$ \\
\hline $\begin{array}{l}\text { - Relationship building focussed at } \\
\text { senior levels }\end{array}$ & $\begin{array}{l}\text { - Relationship building and networking at } \\
\text { all levels }\end{array}$ \\
\hline $\begin{array}{l}\text { - Debating and challenging amongst } \\
\text { small coterie }\end{array}$ & $\begin{array}{l}\text { - Encouraging debate and challenge at all } \\
\text { levels }\end{array}$ \\
\hline $\begin{array}{l}\text { - Carefully prescribed delegation and } \\
\text { empowerment }\end{array}$ & $\begin{array}{l}\text { Providing others with space and } \\
\text { autonomy to experiment, stimulating } \\
\text { bottom up change }\end{array}$ \\
\hline $\begin{array}{l}\text { - Tendency to influence through } \\
\text { operational control }\end{array}$ & $\begin{array}{l}\text { - Influencing by focussing on broad } \\
\text { direction }\end{array}$ \\
\hline $\begin{array}{l}\text { Working on formally agreed } \\
\text { priorities/issues }\end{array}$ & $\begin{array}{l}\text { Working outside as well as inside of } \\
\text { agreed responsibilities, often on } \\
\text { unofficial initiatives }\end{array}$ \\
\hline $\begin{array}{l}\text { - Challenging through established } \\
\text { processes }\end{array}$ & $\begin{array}{l}\text { - Challenging the status quo, irreverent } \\
\text { and subversive }\end{array}$ \\
\hline - Exclusive and Involving of few & - Inclusive and involving of many \\
\hline $\begin{array}{l}\text { Representing legitimate organization } \\
\text { interests e.g. own department, } \\
\text { customers }\end{array}$ & $\begin{array}{l}\text { - Also representing the interests of quasi } \\
\text { legitimate constituencies, often external } \\
\text { to own responsibilities, e.g. other } \\
\text { functions, unofficial issues }\end{array}$ \\
\hline
\end{tabular}


This latter cluster of managers was delineated from the rest of the sample by a combination of factors which serve to define or distinguish the conception of political leadership used here: (a) each viewed diversity of interest as a critical organising principle; (b) this encouraged an irreverent mindset in which individuals felt able to make a personal difference by pursuing their own goals; but balanced by an orientation in which personal success was inextricably interwoven with the success of others' agendas; (c) in order to ameliorate accusations of self-interest, individuals gave importance to building legitimacy of action through transparency of motive. Thus in the absence of any formally agreed model of working, these managers, in seeking to operate with the tensions of plurality, seemed to arrive at their own conclusions largely irrespective of organizational circumstance. In consequence, they tended to see themselves, like Glenn Furness as independent of the goals of their organizations, whilst also working within them.

Notwithstanding the steady progress of these kinds of study in recent years, Rousseau and Rivero quite rightly note the paucity of evidence related to organisational democracy in general. In particular, if, as Bacharach (1967) suggests, democracy is thought of as a political method with ethical ends, then we need to understand much more about the interaction between each element (Rousseau and Rivero, 2003). For example, based on the literature explored here, how is the relationship between politics and democracy enacted in practice? Do democratic practices reduce the likelihood of organizational politics (Rousseau and Rivero, 2003) or can political leadership influence greater organizational democracy? To what extent does political leadership enable individuals to be critically self-reflective - to deliberate, judge, choose and act upon courses of action? Do they genuinely believe their interests are furthered by political leadership or merely subject to a more subtle form of organizational control? How is obedience generated (Courpasson and Dany, 2003) and to what extent were those working with this mindset able to make ethical choices (Watson, 2003)?

My relationship with the Chief Operating Officer of Brokingplc, who attended an open executive development programme at the business school for which I work provided an opportunity to explore more fully explore these research questions. Brokingplc, founded in 1961, originally began trading as a training business. The founder's son John joined the business in 1978 and soon began expanding the trading activities away from training to broking. Floated in 1989, there were at the time of research seven major institutional investors with John retaining $18 \%$ of the 
stock and a seat on the board. In the past 20 years the company has grown year on year mainly through both product and geographic expansion. Offices were opened in Europe, USA, and the Gulf States. These offices were set up and run on the basis of finding specific individuals, highly regarded in the industry, who then grew their own small business. The offices thus developed organically, usually enjoying profitability within two years. By 2008 turnover had reached $£ 250$ million, and the company was operating with 260 employees from 23 offices worldwide.

During the period of research, under the executive plc board, a trading board, led by the Chief Operating Officer (Luke), controlled most business unit strategy, corporate strategy being the focus for the executive board comprised of Tom, (CEO), Margaret, (FD), John and two non executive directors. In 2007, I was invited by Luke to provide a process for upward performance feedback for Margaret, Tom and for himself. From the data collected it became apparent that Luke appeared to employ many of the behaviours and actions of political leadership identified in Clarke (2006) and therefore provided a potential opportunity to explore the impact of political leadership in context. The subsequent agreement with these three directors to research the experience of those working with Luke between January 2008 and February 2009 provides the basis for the following study of political leadership in action.

\section{RESEARCH STUDY}

\section{Data sources and collection}

In order to explore the sensitive research questions identified above in the evolving context of Brokingplc it was agreed with Luke that data would be derived from a number of semi structured interviews with a cross-section of staff and managers deliberately phased over 12 months. Ten individuals were selected in collaboration with Luke on the basis of providing a range of 'supporters, opponents and doubters' (Pettigrew, 1990) of his approach to leadership. These included staff (2), Team Leaders (3) and Managers (4) directors (1); based in France (1), Germany (1), the US (1) and the UK (6). The focus for these conversations was to understand the interviewees' perceptions of the cultural context of Brokingplc, their view of their own experience within this, and their relationship to Luke. These recorded interviews typically lasted around 90 minutes and were personally transcribed. Two extensive recorded interviews and several ongoing conversations were held with Luke himself over the 12 months. 
The interview was designed in three parts around 14 broad themes, developed to surface the constructs that each manager used to make sense of and negotiate their role and relationships in Brokingplc. The first part explored the participant's perception about the enactment of key organizational activities such as goal setting and change management, as these were likely to surface views about the distribution of power in Brokingplc. The second part explored the participant's perceptions about their own role, influence and autonomy. For example, questions included "how do you go about initiating change in Brokingplc? Finally, participants were asked about their relationship with Luke, his approach to leadership and his impact upon the business. Using a laddering technique, 'how' questions were used to surface behaviour, followed by questions such as "what causes you to work in this way" to surface a logic of action (Buchanan, 1999). Validity was further enhanced through interviewees being encouraged to illustrate responses with anecdotes, as these can reveal tacit thinking and organization routines not easily surfaced through other methods (Ambrosini \& Bowman, 2002). Rich data were also gathered from a variety of settings including office events and meetings, some chaired by Luke, and secondary sources such as internal emails, internal and external (industry) blogs, documents, and the company's website. Early (non attributable) findings were discussed with Luke, and his observations incorporated into subsequent analysis.

Confidentiality was assured to all and care was taken to be as reflexive as possible (Easterby Smith \& Malina, 1999) in both the data collection and subsequent analysis. This reflexivity was also enabled by the temporal nature of the research which permitted an iterative process of deductive and inductive analysis. In effect, this allowed me to form mini-cases through which emerging theoretical propositions could be explored and assessed within the interview structure (Denis et al., 2001). Interpretations from one event/interview served as a basis for understanding the interaction between myself and other sources of data. For example, as the data from initial observations about the culture of Brokingplc coalesced around particular themes; more emphasis in later data collection was focussed on interpreting individual motivations and actions.

\section{Data analysis}

Initial coding was established using a framework derived from the work of Clegg (1990) and Gordon (2007) and Gordon et al. (2009). That study, being similarly concerned with the language of power relationships, facilitated a focus on exploring 
the nature and effects of domination, democracy, and methods of power differentiation and de-differentiation. On this basis, and following Gordon (2009), domination was defined in terms of text which reflected unquestioned acceptance of a particular individual's or group's right to power, as for example, in the statement, "Tom and Margaret give out targets and that's it...." Differentiation referred to text where power relations were seen in terms of clearly defined differential boundaries, as with the statement, "people can be overridden, some people might not be asked for their views....... whether they have an opinion or not". De-differentiation referred to established differential boundaries being blurred, usurped of challenged, as in the example, "I spoke to [my boss] and said 'you asked my opinion on this, and then you changed your view and didn't tell me and for now I will not discuss it any more but sometime soon I will raise it again....." Democracy, following the definition above, was to be observed where opportunities to reflect critically, judge and make choices were legitimised in organizational practice, as with the comment, "I will gauge opinion, I will lobby for support, I will debate issues before they get to the board so that there is a greater chance of consensus".

Also following Gordon, et al. these categories were then further sub-coded in terms of the extent to which they were representative of 'structures', 'forms', 'behaviours' and 'effects.' However, these definitions were adapted to fit more appropriately the context of Brokingplc and the focus of this study. So, for example, rather than limit the allocation of 'structures' to architectures and processes that constrained behaviour, such as hierarchy, the allocation parameters were widened to encompass the possibility of hierarchy being used to enhance and legitimise democratic choice. For example, hierarchy was seen by some as a career path to enhance choice and de-differentiation, rather than as simply a reflection of authority. Similarly, 'forms' provided examples not only of 'subtle and less readily observable' instances of constraint, but also of less easily identifiable forms of emancipation. For example, the way in which covert political lobbying and positioning might be used to construct space for resistance, challenge and debate. 'Behaviours' reflected examples of how each of the four main categories (domination, differentiation, de-differentiation and democracy) were enacted as a behavioural practice, as well as examples of the 'effects' of each, that is, the impact these four categories had on others in the business.

In effect, this approach allowed an examination of how events and actions could be viewed similarly or differently by various actors, and thereby highlighted the way in 
which power was exercised and open to interpretation and negotiation and in a process of 'becoming' (Chia, 2002), rather than being seen as fixed or stable. The approach is represented in Figure 2, items appearing in more than one category reflecting their varied interpretation. The development of this analysis also highlighted the connections and inter-subjectivity (Stewart, 1998) between action and structure, and enabled a detailed exploration of the interaction between the unique context of Brokingplc, the behaviours and motives of Luke, and the impact his leadership style was perceived to have on the experience of those within the business.

Figure 2 Connections between action and structure

\begin{tabular}{|c|c|c|c|c|}
\hline & Structure & Form & $\begin{array}{l}\text { Behaviour/ } \\
\text { Practice }\end{array}$ & $\begin{array}{l}\text { Effect on others in } \\
\text { Brokingplc }\end{array}$ \\
\hline Domination & $\begin{array}{l}\text { Centralised control } \\
\text { Financial policy } \\
\text { Hierarchy } \\
\text { Targets } \\
\text { Rank } \\
\text { Capital ownership }\end{array}$ & $\begin{array}{l}\text { HQ centric } \\
\text { UK centric } \\
\text { Short termism }\end{array}$ & $\begin{array}{l}\text { Intransigence } \\
\text { Exclusion } \\
\text { Paternalism }\end{array}$ & $\begin{array}{l}\text { Compliance } \\
\text { Resignation } \\
\text { Subordination } \\
\text { Resistance }\end{array}$ \\
\hline Differentiation & $\begin{array}{l}\text { Hierarchy } \\
\text { Closely } \\
\text { circumscribed roles } \\
\text { Mission statement } \\
\text { GP reporting process }\end{array}$ & $\begin{array}{l}\text { Managerial } \\
\text { dominance } \\
\text { Experience } \\
\text { Strategy as the } \\
\text { purvey of senior } \\
\text { management } \\
\text { CEO blog }\end{array}$ & $\begin{array}{l}\text { Resistance to voice } \\
\text { Prioritising } \\
\text { shareholders } \\
\text { Prioritising plc over } \\
\text { BU } \\
\text { Silence } \\
\text { Selective } \\
\text { communication }\end{array}$ & $\begin{array}{l}\text { Frustration } \\
\text { Cynicism } \\
\text { Constraint }\end{array}$ \\
\hline De- differentiation & $\begin{array}{l}\text { Communication } \\
\text { cascade } \\
\text { Management } \\
\text { development } \\
\text { Cross hierarchy } \\
\text { ops group } \\
\text { Management } \\
\text { Training Scheme } \\
\text { Mission statement } \\
\text { Hierarchy/Career } \\
\text { Path }\end{array}$ & $\begin{array}{l}\text { Industry blog } \\
\text { Working outside } \\
\text { of formal } \\
\text { responsibilities } \\
\text { Personal } \\
\text { agendas }\end{array}$ & $\begin{array}{l}\text { Challenge/ } \\
\text { questioning } \\
\text { Perseverance } \\
\text { Irreverence } \\
\text { Political positioning }\end{array}$ & $\begin{array}{l}\text { Confidence } \\
\text { Identity forming } \\
\text { Longer term view } \\
\text { Greater openness } \\
\text { Suspicion }\end{array}$ \\
\hline Democracy & $\begin{array}{l}\text { Hierarchy/Career } \\
\text { path } \\
\text { Processes of } \\
\text { inclusive } \\
\text { representation } \\
\text { Inclusive training/ } \\
\text { development } \\
\text { Mission statement }\end{array}$ & $\begin{array}{l}\text { Decentralised } \\
\text { ethos } \\
\text { Legitimised } \\
\text { networking/ } \\
\text { politics } \\
\text { Cross BU } \\
\text { communication } \\
\text { Cultural diversity } \\
\text { Space } \\
\text { Bottom up } \\
\text { strategising }\end{array}$ & $\begin{array}{l}\text { Seeking opinion } \\
\text { Encouraging self } \\
\text { reflection } \\
\text { Conflict resolution } \\
\text { Transparency of } \\
\text { agenda } \\
\text { Encouraging } \\
\text { debate/voice }\end{array}$ & $\begin{array}{l}\text { Ethical assertiveness } \\
\text { Experimentation } \\
\text { Resilient trust } \\
\text { Self respect } \\
\text { Autonomy } \\
\text { Self development } \\
\text { Choice } \\
\text { Mutuality }\end{array}$ \\
\hline
\end{tabular}




\section{AN INTERPRETATION OF LIFE IN BROKINGPLC}

\section{The context}

There was almost universal agreement that Brokingplc was changing. For most this was represented as a move from a tightly controlled UK centric group of main board directors/shareholders (John, Tom and Margaret) toward a more open and inclusive business. The characteristics of the 'old' approach were mainly described in terms of educated and highly incentivised brokers who were tasked to concentrate on delivering "GP"- gross profit. Brokers had considerable latitude to make their annual targets (which were usually seen to be handed down without much consultation), but were encouraged to not 'bet the farm'. In consequence, the business model was considered a mixture of commercial aggressiveness, paternalism, and conservative (or at least limited) strategising about future business development. The effect of these structural aspects of domination on employees reflected a history of compliance and cynicism:

".....we are very target driven, everything is on targets, everyday we get targets. It can be de-motivating if you are not hitting them ....working hard, meeting clients and making them come back, but at the end of the day it doesn't matter. (Deborah, Team Leader)".

However, in tension with this established culture, a new discursive framework was seen to be developing. The business was now becoming more open "a very international structure with a low hierarchy, so management is always reachable in my country and I know that I can talk to management in the UK as well" (Babetta, Team Leader). It "invites challenge upwards as well as downwards. [It is] much more expansive, willing to make change".

Much of the tangible evidence for this was ascribed to changes in both structure and form:

"I think the culture is changing, evolving. I think we are going from a small dictatorship and I think we are being dragged kicking and screaming toward,..... what I want to say is a larger democracy.... Previously power has been concentrated in a very few hands. We are finding actually that if you put some rules and some structure to the organization and put a framework around these brokers you do actually add more value than just having a bunch of self motivated prima donnas all doing their own thing. ...." (Jeremy Business Unit Director) 
This suggests that structure was certainly experienced as an instrument of differentiation. However, it was also by others seen as a source of potential empowerment that enabled individuals to fulfil personal aspirations, and as a source of power from which to initiate change. In part, the positive orientation toward these structural phenomena was associated with emerging de differentiated forms and behaviours reflected in managerial attitudes towards organizational politics, often role modelled by Luke. Networking, developing power bases, agenda setting, and the existence of overt and covert agendas were all positively and routinely reflected in the interviews at many levels of the business. Grades and career paths were therefore often used as opportunities to further individual causes through which de-differentiation could occur, as recently promoted Daniel (Business Unit Manager) suggests:

"I am a good advocate for change .... I try and build relationships across the group in order to promote that change. I kind of see myself as a pivot between senior management and the rest of the organization in trying to push changes through...... The structure in Brokingplc gives me the autonomy to do that and I'm taking full advantage of that, and now that I have been given that chance it really excites me to get involved on a group level to bring people up with me"

Where for Daniel, 'bringing people up with me' reflected "a lot more communication throughout the group", employees "contributing their ideas to the strategy" [and] "debate being pushed to lower levels of the organization".

Frequent mention was made of 'pushing changes forward'. When this aspiration was explored in more detail it sometimes reflected, as with Daniel's perspective, a way of expressing a private agenda, but also on occasions reflected a functionalist rationality about meeting shareholder return or improving the efficiency of the business. In part this was commensurate with the priorities of the executive board, that traditionally focused on forms of financial control and short term targets, enforced through behaviours such as selective communication/involvement, managerial dominance, intransigence and resistance to issues raised. In contrast, much of the language of the trading board, controlled by Luke was concerned with de-differentiation; dispersing power through processes of decentralised strategy making and participation. 


\section{Luke: behaviour and motives}

Luke, in his mid forties, started his career as a milkman but has worked for Brokingplc for the last 16 years. During that time he has moved from a broking role to the executive board. Most in the business spoke of him having changed his interpersonal approach substantially as he assumed greater positions of responsibility. At the time of the study, in all respects Luke's behaviour was consistent with the description of political leadership described in figure 1 , and this behaviour served to legitimise political activity for many within the business. This behaviour was seen as constructive because of Luke's positive orientation toward personal development, transparency of agenda, debating issues widely, providing space for experimentation and informal processes of influencing. For example, after his promotion to the executive board Luke continued working without a private office, placing himself in the centre of the trading teams, accessible to all at HQ:

"He encourages debate, he encourages discussion, he encourages challenging, he's open to new ideas, he's keen to develop a team around him that he can trust. I think he uses politics very adeptly and cleverly. At the end of the day everyone trusts his objectives,..... he trusts you to let you run your business, to get on with $i t, . . .$. and I think he is a very supportive voice for all of us.....(Jeremy, Business Unit Director)

This supportive voice extended to those who were outside his official area of responsibility through keeping others updated with 'what was going on', providing developmental input to them, and in doing so, building trust beyond the boundary of his official role. As in Clarke (2006), this orientation appeared to be driven by a belief in the value of plurality that in turn legitimised the value of personal agendas, and thus the necessity for constructive models of political behaviour. The acknowledgement of the multiplicity of agendas and values at play appeared to force him to confront a number of ethically contentious issues, for example between the traditional expectations upon executive directors in Brokingplc, including the commensurate requirement for differentiation on the one hand, and his personal values of inclusion and the need for de-differentiation on the other:

"What we tended to do in the past is to order people - this is the way we are going to do it. We have not received buy in, we have not solicited the views of others. We have just said that is the way we do it in the UK so that's the way you do it in Germany, France and the US. We don't give a 'monkeys' about your culture or 
where you see different issues... For me, you've got to listen to people, respect their culture, respect doing things in a different way and as result of that allow them to express themselves.... For me it's really important that we try and include as many people as we can and listen to their opinions and advice and ideas......" (Luke)

A further illustration of this need to address ethical dilemmas lies in his concern to balance his own personal desire to further interests of others and to work ethically but profitably with customers:

"I am motivated to do the best for other people and the company and I get a huge kick out of it when I see myself and other people achieving things they could not achieve in many other places. And that's what I love. I want to see people express themselves and achieve things......and do the best they possibly can in a work environment." (Luke).

"But sometimes that 'expressing oneself' might butt up against the imperatives of making money...?" (Author).

"Yes, there is a compromise going on there. We do have to make money, but it's the way we make money. It doesn't have to be done so arrogantly. For example we can screw someone for $€ 50,000$ on a cancellation, but we have to be bloody ethical as well. And sometimes we cross over that line and can be unethical in the way we do business in certain cases...and that is the old school and that is not the way I want it to be" (Luke).

\section{The impact of Luke's approach}

The impact of Luke's motives and behaviour were discernable at both an organizational and personal level. At the organizational level the views were almost entirely consistent that Luke was the architect of the changes at Brokingplc, even despite doubts having been expressed about his chances of encouraging change on his promotion to the executive board:

"He has radically reshaped the business. What he has achieved in the environment he has come into is quite astonishing. He has been honest enough to say, look I don't know everything, we all have our limitations if you like, but we can all improve ourselves..... I think that's a hugely important principle. (Jeremy, Business Unit Director). 
This radical shift included encouraging greater sharing of key information, more autonomous working, and developmental opportunities that served to extend voice and self-determination. Early interviews coincided with one particular incident that is of note. In the spring of 2008, at Luke's suggestion Tom, Margaret and Luke had been formulating a mission statement for the group. Conscious of the danger of this becoming a top-down process Luke ensured that their early formulations were debated throughout the organization as a 'straw man'. This resulted in a key word in the statement, being contested by many staff. Tom, whose choice of word this was, resisted any change, such that some mangers were perceived to be frustrated by this intransigence and expressed cynicism about the sincerity of the participation process. Luke nevertheless persisted in generating debate about this issue which eventually led to Tom acquiescing, something he was perceived rarely to do. It was considered a significant incident in which the power of the directors was seen to have been collectively challenged from below, and this built confidence to pursue other opportunities for de-differentiation.

Even more striking was the effect that Luke had at a personal level, not just with his direct reports but with peers and staff throughout the organization. People consistently highlighted Luke's developmental orientation towards them as evidence of his willingness to take account of others personally, and valued the self-reflection this encouraged in terms of considering alternative courses of action, autonomy and self-identity:

"He wants to see everyone do really well, and so he has challenged me to think differently, and we've had some really good debates about that and you know that really makes you think.... and I think I've learnt a lot from Luke and challenged myself.....and watched other people and how they go about influencing people, how they talk to people so I've been aware of what's going on rather than being busy doing my own thing .... you know..."go away." (Margaret, Finance Director)

"He's had a big impact on me. He's had belief in me and forced me to do training courses I probably wouldn't have done and forced me to take a risk, and I'm not a risk taker. Yes, he's had belief, he's provided encouragement, feedback ....... He was loud and brash. I don't think he saw the impact of that but he's not like that anymore. In the old days no one would have been brave to tell him, I wouldn't, but I would now". (Deborah, Team Leader) 
"We have an open relationship and I have given him feedback in the past, and he takes it on board. He's given me feedback too, I find that interesting, how others see you and you can reflect on the reasons why ..." (Rosie, Broker).

"He helped me to realise....to become less arrogant. If I hit an obstacle, ....let's take Freda as an example. If we disagreed before it would turn into she's a bitch and he's a wanker or something like that - entrenched positions - and that is not a constructive position. And Luke made it very clear, you're two different people but you need to work together. If you just had the time to talk together and get over the short term obstacle you have you might find you have a lot in common". (Jeremy, Business Unit Director)

The impact of Luke's values was particularly noticeable in the appointment of Claude to the role of Quality Manager in November 2008. As a result of an openended conversation with Luke, Claude felt empowered to shape his new role according to his own ethical agenda. This included challenging the use of EU blacklisted suppliers, even though there was no legal or organizational requirement to do so. He subsequently furthered his agenda, in similar ways to Glenn Furness, by positioning his cause as a business case, not simply as an unethical activity.

There were of course criticisms of Luke's approach; his tendency to be too direct about his agenda aroused suspicion in some. Sometimes people found him insensitive to the needs of certain staff and too focussed on his own personal interests:

"You either love him or hate him. About $80 \%$ of people both respect and like him and I like his style very much." (Judy, Broker)

Aware of this perception, both solicited and given freely, Luke attempted to ameliorate this perception by consulting widely, trying to understand others agendas, attempting to find win-win outcomes, and being honest about the potential negative consequences of decisions.

\section{DISCUSSION}

How should these observations be interpreted? To what extent is Luke's orientation toward political leadership furthering democratic working? Certainly there are many contextual features that might encourage levels of employee participation regardless of Luke's intervention. For example, Tom and Margaret have generally 
recruited well-educated self-starters and organised them in relatively small semiautonomous units. However, given that instrumental obedience, centrally determined financial rules and individual accountability are all notable features of Brokingplc, these factors should perhaps be considered as merely reflective of the features of 'bureaucracy lite'. For some employees, therefore, the drive to "move the business forward" might be viewed as a reflection of structural domination, a form of 'dependable autonomy', where identity control is exercised through a form of enforced democracy. In this circumstance, managers adopt apparently independent behaviours, but these ultimately align with the organization (Robertson \& Swan, 2003).

However, application of the adapted Gordon/Clegg model to data collected over different points in time surfaces the way in which identity, control and autonomy were open to individual interpretation and negotiation. In particular, it highlights the interaction between micro practices and institutionalised power structures in the on going negotiation of order and the process of transition this enabled. For example we can see that, for some actors, the willingness to accept increased levels of role definition appears more redolent of 'an absence of choice for good reason' (Courpasson \& Dany, 2003) in which individuals were making private choices about what forms of organizational control/structure were acceptable in order to further the success of the business. This can be seen reflected in Jeremy's willingness to embrace greater structural constraint in order to curtail the unnecessary individualism of 'prima donnas', even though this potentially risked greater role differentiation. In so much as Luke is seen as the architect of the changes in Brokingplc, perhaps we can begin to see here an impact of Luke's agency. More specifically, Luke's legitimisation of political activity and debate has provided opportunities for staff to use these structures for both personal and organizational gain. For Luke, this legitimisation was achieved though his developmental orientation and the way in which he encouraged others to pursue their own particular interests, either personal or/and organizational.

In consequence, structures such as hierarchy, business divisions and management development programmes were often perceived as vehicles for furthering independent agendas as well as instruments of differentiation and domination. This was reflected, for example, in the challenge to the mission statement and in the way Daniel defined his identity as an advocate of change "to bring people up with me". This combination of obedience and legitimised politics seemed to engender a 
level of resilient trust that indeed appeared to facilitate organizational cohesion (Courpasson \& Dany, 2003).

Luke's political orientation also appears to be integral to his ethical assertiveness (Watson 2003). By valuing a plurality of interests and perspectives commensurate with the political leadership identified in Clarke (2006), he is inevitably forced to work through an ethically irrational world of conflicting demands, for example, threading a path between the need for hierarchical control and the importance of debate, or between the commercial drivers of success and his desire to treat customers fairly. In this way we can see Luke as a moral actor. A key value for Luke is a passionate desire to further the interests of others; "to see people express themselves and achieve things". Courpasson and Dany (2003: 1249), quoting Selznick, note that for a community to be strong, there must be a desire to further the interests of others, not merely to give them the consideration they deserve as moral equals. By working in a way that reflected the implicit mutuality of individual goals, and thus the need to further the interests of others rather than merely taking others' views into account, this approach might also be seen as encouraging the formation of just such communities, or in Courpasson and Dany's terms the formation of 'democratic hybrids'.

We can also discern that Luke's open developmental approach, enacted from a political perspective, served to reveal his aspiration for others and encouraged a different discourse about the possibilities for them, quite distinct from the previous focus on gross profit. Luke did not restrict himself to working with hierarchical relationships in these conversations, but also worked with peers and those outside of his direct authority. Examples are plentiful: encouraging self-reflection in Margaret (his peer) about her role, encouraging Jeremy to work with a mutuality of interests, or helping Deborah to build greater assertiveness, with its concomitant implications for de-differentiated behaviour. Luke's open approach to the Quality Manager role provided opportunity for Claude to further his own ethical agenda. For Clegg, et al. "when ethics is something one does rather than something one has, then this 'doing', organizationally, is enhanced by the opportunity for debate...discussion and dialogue" (2007: 117). Encouraging debate and challenge (both to and from Luke) were consistent descriptions of his approach, suggesting both a fertile territory for ethical considerations and for blurring differential power boundaries. This was demonstrated, for example, in the confidence with which 
Rosie, a junior employee, had provided Luke with critical upward feedback, and in Luke's attempts to diffuse the concentration of power at board level.

That said, economic power was certainly retained in the hands of shareholders (Luke, too, has a small stock option), and the ability for most to conclude debate about organizational priorities remained limited. Yet in Luke's personal agenda and his political orientation, enacted through a range of organizational initiatives, we can perhaps see the emergence of greater democratic practice. Organizational democracy was defined earlier as in terms of enhanced individual autonomy and the legitimisation of processes that enable individuals to be critically self-reflective to deliberate, judge, choose and act upon courses of action. The extent to which Brokingplc employees were developing a critical perspective on the hegemony of managerialism is probably restricted to a few individuals. Nevertheless, Luke is questioning such controls and together with a few others, seeking to enhance individual freedom and disperse power more democratically across the business. Luke's legitimisation of political activity has also served to mediate between the acceptance of organizational controls such as financial policy and the private aspirations of others for autonomy, choice and career. Critical reflection to achieve self-knowledge is the basis for individual freedom and ethical action, and in this regard, many of those participating in this study might be seen to be at the beginning of such a process.

\section{CONCLUSION}

This interpretation of the interpretations of life in Brokingplc is a joint process between researched and researcher. As such, the objective is not to seek generalisability in the links between Luke's behaviours and the emerging characteristics of Brokingplc. There are too many rich contextual features, let alone unique aspects of Luke himself to permit such conclusions. Nevertheless, following the epistemology applied here, what we can see is that certain types of behaviour and outcomes are possible in certain contexts. By exploring workplace democracy from the perspective of civic virtue; the beliefs, values and behaviours that support participation, trust and accountability (Rousseau and Rivero, 2003), the study has been able to illuminate the potential value of Hendry's proposition that political leadership may have a significant role to play in building communities of trust.

As Rousseau and Rivero note, democratic cultures take time to develop and this study provides some insight into how this process may be enabled. By exploring the 
everyday experience of political leadership we can see how the micro practice of politics, legitimised through hierarchical power relations shaped the democratic context of Brokingplc. In that sense, politics both diminished and enhanced the asymmetric power relations within the business. Luke's legitimisation of individual agendas served to encourage voice but in doing so implicitly reinforced obedience. We see here then, evidence to support the notion of democratic hybrids conceptualised by Courpasson and Dany (2003), the hallmarks of which are: (1) the hybridization of processes that enable people to act under relatively close supervision whilst allowing for moral conduct; (2) levels of participation in community structures but with limited opportunity to conclude debate, and (3) which depend on the emergence of moral consciousness. These aspects can be seen, for example, in Jeremy's acceptance of structural constraint for collective good, the aspirations of Daniel to extend strategic debate within the prevailing hierarchy, and Claude's personal ethical agenda.

These features are becoming integrated into the culture of Brokingplc through Luke's political leadership orientation which influences and is influenced by the routine collective negotiation over order and control. Luke did not articulate any lofty design to democratise his business, but his more modest desire for people to 'express themselves and achieve things' is reflective of deeper values. This suggests that Luke is indeed exercised by the ethical choices involved in the wider design and development of Brokingplc, which, albeit influenced by a number of factors, can be considered as becoming more democratic. Luke's ethically assertive agenda and developmental orientation was most importantly enabled through a form of political leadership. Each element acts on the other in a recursive manner; but all three appear to be critical to how power was legitimised in this context. In effect, his developmental approach helped reveal or assure others of his motives. In doing so, this transparency served to legitimise the use of political means in the pursuit of his wider business and personal (ethical) agenda. It can be argued therefore that Bacharach's (1967) view of democracy as a political means to an ethical end is as valid in the workplace as it is in society generally.

For Bacharach, the ethical ends are conceived in terms of education, advancement and development. In an organisational context, the study similarly surfaces the importance of personal development and advancement, but as both a means and an end in the process of democratization. Encouraging self reflection in colleagues, upward feedback from junior staff and greater assertiveness to challenge the 
hierarchy, all contributed to de-differentiated action and opportunity to express voice. Such nascent critical self reflection is suggestive of democratic intent in so much that it provides the basis for scepticism, and promotes a wider range of values and viewpoints (Dehler, 2009).

Levels of domination of course persist, but hierarchy and democracy will always be in tension, if they are both essential aspects of organising. Perhaps the political perspective explored here serves as a relational synthesis (Clegg, 2003) in which more of one does not necessarily mean less of the other. The interaction between ethical assertiveness, political action and a developmental orientation may serve to extend the analysis of Poff (2007) and others as to the antecedents of moral leadership in business. As Poff highlights, there is now, more than ever, a need to understand what influences the development of moral reasoning in everyday managerial work, and this is the focus of our next project.

\section{REFERENCES}

Ambrosini, V. \& Bowman, C. (2002) Mapping Successful Organizational Routines in S. Huff, and M. Jenkins, M. (eds.) Mapping Strategic Knowledge, pp 19-39. London: Sage.

Armbruster, T. and Gebert, D. (2002) Uncharted Territiories of Organizational Research: The case of Karl Poppers's Open Society and Its Enemies, Organization Studies Vol. 23, 169-188.

Brown, M. \& Trevino, L. (2006) Ethical Leadership: A Review and Future Directions, The Leadership Quarterly 17, 595-616.

Buchanan, D. (1999) The Logic of Political Action: an Experiment with the Epistemology of the Particular, British Journal of Management 10, S73- S88.

Burns, J. M. (1978) Leadership. New York: Harper and Row.

Caldart, A. \& Ricart, E. (2004) Corporate strategy revisited: a view from complexity theory. European Management Review 1, 96-104.

Chia, R. (2002) The Production of Management Knowledge: philosophical Underpinnings of Research Design, in D. Partington (Ed.) Essential Skills for Management Research, pp.1-19. London: Sage. 
Child, J. \& McGrath, R. (2001) Organizations unfettered; organizational form in an information-intensive economy, Academy of Management Journal 44, 1135-1148.

Clegg, S. (1990) Modern Organizations. London: Sage

Clegg, S. (2003) Strange Fruit Hanging from the Knowledge Tree, or Carry on Carping. Management Learning 34, 375-378.

Clegg, S., Kornberger, M. and Rhodes, C. (2007) Business Ethics as Practice. British Journal of Management 18, 107-122.

Cloke, K. \& Goldsmith, J. (2002) The End of Management and the Rise of Organizational Democracy. San Francisco: Jossey Bass

Coopey, J. \& Burgoyne, J. (2000) Politics and organizational learning, Journal of Management Studies 37, 869-885.

Collins, D. (2001) The Ethical superiority and Inevitability of Participatory Management as an Organization System, Organization Science, 8 489-507.

Courpasson, D. \& Dany, F. (2003) Indifference or Obedience? Business Firms as Democratic Hybrids, Organization Studies 24, 1231-1260.

Dehler, G. (2009) Prospects and Possibilities of Critical Management Education: Critical Beings and a Pedagogy of Critical Action, Management Learning 40, 31-49. de Jong, G. \& van Witteloostuijn, A. (2004) Successful corporate democracy: sustainable cooperation of capital in the Dutch Breman Group, Academy of Management Executive 18, 54-66.

Denis, J., Lamothe, L. \& Langley, A. (2001) The dynamics of collective leadership and strategic change in pluralistic organizations, Academy of Management Journal $44,809-837$.

Du Gay, P. (2000) In Praise of Bureaucracy. London: Sage

Easterby-Smith, M. \& Malina, D. (1999) Cross-cultural Collaborative Research: towards reflexivity, Academy of Management Journal 42, 76-85.

Etzioni, A. (1998) A communitarian note of Stakeholder Theory, Business Ethics Quarterly 8, 679-691. 
Gaumitz, B. R. \& Lere, J. C. (2004) A Classification Scheme for Codes of Business Ethics Journal of Business Ethics 49, 329-335.

Gordon, R. (2007) Power, Knowledge and Domination. Liber: Sweden

Gordon, R., Clegg, S. \& Kornberger, M. (2009) Embedded Ethics: Discourse and Power in the New South Wales Police Service, Organization Studies 30, 73-99.

Grint, K. (2002) What is leadership? From Hydra to Hybrid, paper presented at the $1^{\text {st }}$ EAISM Conference on Leadership Research, December, Oxford, England.

Grit, K. (2004) Corporate Citizenship: How to strengthen the social responsibility of managers? Journal of Business Ethics 53, 97-106.

Hales, C. (2002) Bureaucracy-lite' and Continuities in Managerial Work, British Journal of Management 13, 51-66.

Harrison, J. \& Freeman E. (2004) Is organizational democracy worth the effort? Academy of Management Executive 18, 49-53.

Held, D. (1987) Models of Democracy. Cambridge: Polity Press.

Hendry, J. (2006) Educating Managers for Post Bureaucracy, the role of the Humanities, Management Learning 37, 267-281.

Johnson, P. (2006) Whence democracy? A review and critique of the conceptual dimensions and implications of the business case for organization democracy. Organization 13, 245-274.

Kerr, J. (2004) The limits of organizational democracy, Academy of Management Executive 18, 81-95.

Lijphart, A. (1999) Patterns of Democracy. Government Forms and Performance in Thirty Six Countries, New Haven CT: Yale University Press.

Lovell, A. \& Fisher, C. (2003) Business ethics and values. Harlow: Pearson Education.

Luhman, J. (2006) Theoretical Postulations on Organization Democracy, Journal of Management Inquiry 15, 168-85. 
March, J. \& Olsen J. (1995) Democratic Governance. NY: Free Press.

Morrell, K. and Hartley, J. (2006) Ethics in Leadership: The case of Local Politicians, Local Government Studies 32, 55-70.

Painter-Morland, M. (2008) Business ethics as practice: ethics as the everyday business of business. Cambridge University Press.

Peele, G. (2005) Leadership and politics: a case for a closer relationship? Leadership, 1, 187-204.

Pettigrew, A. (1990) Longitudinal Field Research on Change: Theory and Practice, Organization Science 1: 267-92.

Peters, R. and Williams, C. (2002) Does Organizational leadership Theory Apply to Legislative Leaders, Organizational Dynamics 30: 257-268.

Poff, D. (2007) Duties owed in serving students: The importance of teaching moral reasoning and theories of ethical leadership in educating business students, Journal of Academic Ethics 5: 25-31.

Robertson, M. and Swan, J. (2003). Control-What Control? Culture and Ambiguity Within a Knowledge Intensive Firm, Journal of Management Studies 40, 831-858.

Rousseau, D. and Rivero, (2003) A. Democracy, a Way of Organizing in a Knowledge Economy, Journal of Management Inquiry 12, 115-134.

Stewart, A. (1998) The Ethnographer's Method. Thousand Oaks, CA: Sage Thompson, P. and Davidson, J. (1995) The continuity of discontinuity: Managerial rhetoric in turbulent times Personnel Review 24, 17-34.

Vigoda-Gadot, E. and Drory, A. (2006) Handbook of Organizational Politics. Cheltenham, UK: Edward Elgar Publishing, Watson, T. (2003) Ethical Choices in Managerial Work: the scope for moral choices in an ethically irrational world, Human Relations 56, 167-185. 